\title{
The commercial manufacture of compressed diets for laboratory animals*
}

\author{
By J. CAssidy, Minsal Ltd, Northwich, Cheshire
}

The total tonnage of compressed diets for laboratory animals manufactured yearly in this country amounts to only a few hundred tons and, compared with the millions of tons of rations manufactured for farm animals, the amount is very insignificant. I draw this comparison to make the following point which, owing to the relatively small business potential in this market, may not receive the attention and care it merits. Many manufacturers would not consider it worthwhile to enter the market whereas others may do so simply because it means some additional business, but they may not be prepared to recognize that it is a specialized market and should be treated as such. At the present time there are a number of manufacturers of these diets and obviously the volume of business going to anyone is very limited. We must recognize of course, that this market is not easy to serve. Most centres require only a few cwt. at a time which obviously means that the manufacturer must be prepared to manufacture small amounts frequently, in order to supply the diets in the fresh condition which his customer expects. I think that one can reasonably assume, however, that the physical condition of the diets from all sources with regard to freshness and their ability to stand up to transit without undue crumbling is reasonably good-if this is not so then the customer is to blame for accepting inferior goods. But what about regularity of chemical composition? It is true that the formulas for the various diets have been laid down but unfortunately there have been no standards set for the quality of the individual ingredients used in the diets-at least this is true for the diets with which we are concerned. One can be assured then of regularity of composition in respect of the percentages of ingredients used, but not so in respect of regularity of chemical composition unless the manufacturer is prepared to give his attention to this matter.

I submit that his first duty is to decide on a standard for each of the individual ingredients used in the make-up of the diets, and furthermore having done so be prepared to adhere to these standards.

In our business we are concerned with diets based on formulas for diets I 8 (Bruce \& Parkes, I947) and 4I (Bruce \& Parkes, I949). The changes which we have made were to introduce a trace-element supplement to replace the $\mathrm{I} \%$ salt and $\mathrm{I} \%$ chalk in diet $\mathrm{I} 8$ and in diet $4 \mathrm{I}$ to replace the cod-liver oil by a stabilized preparation of vitamins $A$ and $D$ and the salt by the trace-element supplement. These changes are clearly stated in our advertising literature.

The compositions of the diets are shown in Table $\mathrm{I}$.

- Presented on behalf of H. C. Styles (Bewdley) Ltd, Worcs, and Oxo Ltd, Thames House, Queen Street, London, E.C.4. 
Table 1. Percentage composition of diets

Diet $\mathbf{x} 8$

(rabbits and guinea-pigs)

Bran

Dried-grass meal

Groundnut cake $\quad$ is

Linseed cake Io

Barley meal

Meat-and-bone meal

Trace-element supplement
Diet $4 \mathrm{I}$

(rats, mice and monkeys)

Wholemeal flour

Sussex-ground oats

White-fish meal

Dried yeast

Dried skim milk

Stabilized vitam

Trace-element supplement

The elementary analysis of the mineral supplement in both diets is shown in Table 2.

Table 2. Calculated elementary analysis of mineral supplement $(\%)$

$\begin{array}{lc}\text { Calcium } & 21 \cdot 55 \\ \text { Chloride } & 18 \cdot 21 \\ \text { Sodium } & 11.79 \\ \text { Phosphorus } & 3.58 \\ \text { Magnesium } & 1 \cdot 19 \\ \text { Iron } & 0.93 \\ \text { Sulphur } & 0.30 \\ \text { Manganese } & 0.026 \\ \text { Copper } & 0.023 \\ \text { Iodine } & 0.023 \\ \text { Cobalt } & 0.010 \\ \text { Potassium } & 0.006\end{array}$

Specimen batch analyses of the diets are shown in Table 3, and the theoretical analyses in respect of oil, protein and fibre given by Bruce \& Parkes (1949) are shown against the appropriate diet. The theoretical analyses are given in terms of digestible nutrients and when this is borne in mind it will be found that the specimen analyses given agree fairly closely, although in the diet for rabbits and guineapigs the actual protein of the manufactured product is about $3 \%$ higher when considered in terms of digestible protein.

Table 3. Specimen batch analyses and theoretical analyses of diets ( $\%)$

Diet 18

\begin{tabular}{lcc} 
& \multicolumn{2}{c}{ (rabbits and guinea-pigs) } \\
\cline { 2 - 3 } Constituent & Specimen & Theoretical \\
Moisture & 9.8 & \\
Protein & 23.3 & 16.5 \\
Oil & $4 \cdot 1$ & 4.6 \\
Fibre & 9.8 & 6.7 \\
Ash & 8.6 & \\
$\mathrm{CaO}$ & 2.24 & \\
$\mathrm{PaO}_{2} \mathrm{O}_{5}$ & 2.2 & \\
$\mathrm{NaCl}$ & 1.02 &
\end{tabular}

Diet $4 \mathbf{I}$

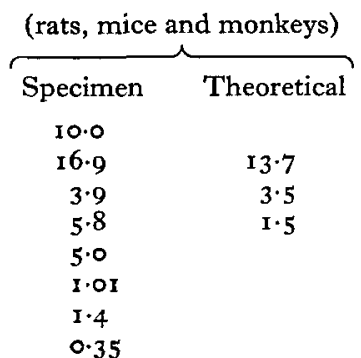

Coming now to a consideration of the individual ingredients which go to make up the diets, we can dismiss with very few words the cereals and the cereal by-products. Barley, oats, wheat and bran are used in one or other of the diets. The quality 
of these products obviously can vary, and more so with the whole grains than with the by-product. We use only home-milled bran and one can reasonably say that this is a fairly standard product. Of wheat, we have available hard wheat and soft wheat, the essential difference being that the hard wheat is higher in protein than the other. We have chosen to use soft English wheat of best quality with bold plump kernels. Of oats, we use only home-grown, and here again these are specially selected to include only varieties with thin husks. The barley is again carefully selected, either home-grown or imported being used depending on the quality of the product available.

To consider now grass meal, we have a product that obviously varies tremendously in quality. The protein content may range from as low as 13 to as high as $26 \%$ and above, and the carotene content from as low as 150 or even less to over $400 \mathrm{mg} / \mathrm{kg}$. Obviously the fibre content also varies greatly depending on the time of cutting, and may be as low as 17 or as high as $25 \%$. This is rather a serious matter because in the diet for rabbits and guinea-pigs grass meal forms no less than $30 \%$ of its composition. Obviously if we consider the wide extremes then a very serious variation in the analysis of the final diet is possible. We use a product of average protein content of $\mathrm{I} 7 \%$ and a carotene content of $290 \mathrm{mg} / \mathrm{kg}$. The fibre content is of the order of $19 \%$.

With the animal-protein supplements, meat-and-bone meal and fish meal, there is again a possibility of products of widely different quality being used, and this possibility is more likely with meat-and-bone meal. This product can contain between 40 and $54 \%$ protein. One is not quite so concerned however, about a posisible variation in protein, and we ourselves standardize at $45-48 \%$, but rather with the possibility of variation in oil content. Meat-and-bone meal is available on the market of oil content as high as $12-14 \%$, and some of the samples which I have seen are not at all attractive. Obviously with such a high oil content the possibility of rancidity development is very real with further possibility of the subsequent destruction of vital nutrients in the finished product, and in particular vitamin $\mathrm{E}$. We insist on a product containing not more than $4 \%$ of oil.

With fish meal it is true that, provided good-quality fish meal is used, one is assured of a product of fairly standard composition, but not so if a manufacturer should substitute herring meal for English white-fish meal. In fairness one must say that the biological quality of the protein in good herring meal is perfectly satisfactory, but here again one is concerned with the possibility of deleterious effects due to the high oil content of the meal, which on average is between 8 and $10 \%$ against the normal $2-4 \%$ of white-fish meal. We find also that with the supplementary vegetable proteins, groundnut cake and linseed cake, there is a possibility of variation in quality. We have standardized by using decorticated groundnut meal of protein content of $51 \%$ and a maximum fibre content of $6 \%$. With linseed-cake meal we use expeller flakes ground into meal, containing 30\% protein and of $8 \%$ oil. Another ingredient, dried skim milk, is a fairly standard product, and there should be little possibility of any serious variation in quality. The final ingredient is dried yeast and we use of course the unextracted product with a protein content of about $46 \%$. 
The compounder has, of necessity, to give serious thought to the manufacture of these diets, and if he is willing to standardize in the way which $I$ have indicated then obviously the final products are of fairly regular composition. On the other hand, if a compounder gives little thought to the possible variation in the quality of his individual ingredients and uses whatever comes to hand, the difference in nutritional quality between one batch and another may be very wide and the results serious.

Concerning the actual manufacturing process, there is not a great deal which one can say. The principle is to inject steam into the dry meal with subsequent compression through a dye. Obviously one can produce pellets of variable size and we offer the modified diet 18 of Bruce $\&$ Parkes (1947) in the form of a $3 / 16$ in. pellet and the other as a $3 / 8$ in. pellet. The material is normally processed in 3 -ton batches.

Obviously it is very important to achieve a thorough mixing before pelleting, and to achieve it the meal is first of all mixed in a horizontal-drum type of mixer from which it is fed into a vertical fountain-type mixer and from there into the pelleting machine. The meal passes from the mixer into the cascader where another mix is achieved through the use of agitators, and during this process steam is injected; the meal is then compressed through a dye. The pellets then pass into an air-cooled vertical cooling chamber, and thence through sieves to the packer. The rate of takeoff depends on the size of the pellet being manufactured and is of the order of $45^{-5} 5^{\circ}$ $\mathrm{cwt}$./ $\mathrm{h}$ for the $3 / \mathrm{I} 6 \mathrm{th}$ in, size and $55^{-60} \mathrm{cwt}$. $/ \mathrm{h}$ for the $3 / 8 \mathrm{th}$ in. size. The meal in the cascader reaches a temperature of about $100^{\circ} \mathrm{F}$. Incidentally there is no binding material added. The pellets are packed in hessian sacks, as packing in such containers avoids the possibility of mould development in the event of the pellets sweating.

\section{REFERENCES}

Bruce, A. M. \& Parkes, A. S. (1947). F. Hyg., Camb., 45, 70.

Bruce, A. M. \& Parkes, A. S. (1949). F. Hyg., Camb., 47, 202.

\section{The assessment of the diets of laboratory animals}

\section{By Gwendoline G. Weeks, Laboratory Animals Bureau of the Medical Research Council, Holly Hill, Hampstead, London, N.W.3}

The title of this paper may appear to embrace too large a subject to be covered in one short paper. Therefore at the beginning I should like to qualify it and say that I am going to deal with criteria that have been used to assess the nutritional adequacy of diets for laboratory animals and then go on to describe a method I have used with special reference to the body composition of rats.

Growth is most commonly used as a criterion to assess the need for a nutritional factor in a diet, because normal growth imposes a great metabolic strain on an animal. 